Article

\title{
Characterization of Subgrid-Scale Variability in Particulate Matter with Respect to Satellite Aerosol Observations
}

\author{
Meredith Franklin ${ }^{1, *(D)}$, Olga V. Kalashnikova ${ }^{2}$ (D), Michael J. Garay ${ }^{2}$ and Scott Fruin ${ }^{3}$ \\ 1 Division of Biostatistics, University of Southern California, Los Angeles, CA 90089, USA \\ 2 NASA Jet Propulsion Laboratory, California Institute of Technology, Pasadena, CA 91109, USA; \\ olga.kalashnikova@jpl.nasa.gov (O.V.K.); michael.j.garay@jpl.nasa.gov (M.J.G.) \\ 3 Division of Environmental Health, University of Southern California, Los Angeles, CA 90089, USA; \\ fruin@usc.edu \\ * Correspondence: meredith.franklin@usc.edu; Tel.: +1-323-442-2703
}

Received: 8 March 2018; Accepted: 13 April 2018; Published: 18 April 2018

\begin{abstract}
Recent use of satellite observations of aerosol optical depth (AOD) to characterize surface concentrations of particulate matter (PM) air pollution has proven extremely valuable in estimating exposures for health effects studies. While the spatial resolutions of satellite data provide far better coverage than existing fixed site surface monitoring stations, they are not able to capture atmospheric processes such as dilution of primary pollutants that vary at small spatial scales. As a result, small-scale variability due to highly localized sources such as traffic may be poorly represented, which in turn may lead to exposure measurement error in epidemiological analyses. Using a fixed spatial grid representing $4.4 \mathrm{~km}$ Multiangle Imaging SpectroRadiometer (MISR) aerosol observations, we examined the spatial variability in fine and coarse mode $\mathrm{PM}\left(\mathrm{PM}_{2.5}\right.$ and $\mathrm{PM}_{2.5-10}$ respectively) measured at ground monitors from a unique spatially-dense sampling campaign in Southern California. We found that while the variance in measured $\mathrm{PM}_{2.5}$ differed seasonally (warm $6.82 \mu \mathrm{g}^{2} / \mathrm{m}^{6}$ and cool $\left.24.5 \mu \mathrm{g}^{2} / \mathrm{m}^{6}\right)$ across the study region, the average subgrid $(<4.4 \mathrm{~km})$ variance did not (warm $2.03 \mu \mathrm{g}^{2} / \mathrm{m}^{6}$ and cool $2.43 \mu \mathrm{g}^{2} / \mathrm{m}^{6}$ ) and was significantly smaller. On the other hand, ground monitor $\mathrm{PM}_{2.5-10}$ concentrations showed large variance in warm $\left(18.6 \mu \mathrm{g}^{2} / \mathrm{m}^{6}\right)$ and cool $\left(20.6 \mu \mathrm{g}^{2} / \mathrm{m}^{6}\right.$ ) seasons, as well as seasonal differences in subgrid variance (warm $8.90 \mu \mathrm{g}^{2} / \mathrm{m}^{6}$ and cool $\left.3.28 \mu \mathrm{g}^{2} / \mathrm{m}^{6}\right)$. Geostatistical analysis of the semivariance as a function of distance indicated that variability in measured $\mathrm{PM}_{2.5}$ and $\mathrm{PM}_{2.5-10}$ concentrations was relatively constant for spatial scales of one to five kilometers, but there was evidence of small-scale $(\sim 500 \mathrm{~m})$ variability in $\mathrm{PM}_{2.5-10}$ concentrations in the cool season. The lack of small-scale spatial variability in the warm season was likely due to large photochemical contributions to regional $\mathrm{PM}_{2.5}$, and greater regional contributions to $\mathrm{PM}_{2.5-10}$ from windblown dust. In contrast, in the cool season there tends to be greater localized concentrations from primary traffic sources due to stronger nocturnal inversions and delayed morning winds reducing dilution that contribute to greater spatial heterogeneity. Overall, these results suggest that regional contributions tend to dominate $\mathrm{PM}_{2.5}$, and spatial resolutions of satellite observations including the $4.4 \mathrm{~km}$ MISR and $3 \mathrm{~km}$ MODIS aerosol products aptly capture relevant spatial variability. Coarse $\mathrm{PM}_{2.5-10}$ can have seasonally dependent localized contributions, leading to small-scale variability below current satellite aerosol product resolutions.
\end{abstract}

Keywords: subgrid variability; aerosol optical depth; $\mathrm{PM}_{2.5} ; \mathrm{PM}_{10}$; spatial scale; variograms; exposure assessment 


\section{Introduction}

Particulate matter (PM) air pollution is of significant public health concern. A large number of epidemiological studies have linked exposure to PM with a variety of adverse health effects including respiratory and cardiovascular diseases, and mortality [1-3]. Children are particularly susceptible; exposure to $\mathrm{PM}_{2.5}$ (PM with aerodynamic diameter $\leq 2.5 \mu \mathrm{m}$ ) early in life can lead to the onset of asthma [4], wheeze [5], and decreased lung function [6].

Particulate matter exposures used in health effects studies are typically estimated by applying spatio-temporal models to a variety of data including measurements from monitoring stations [7], outputs of numerical models [8,9], or satellite observations of aerosol optical depth (AOD) [10-12]. Exposure estimates based on these data are representations of ambient air exposures, but accuracy can be limited by the spatial and temporal detail provided in resolving the variability in PM concentrations $[13,14]$. Types of PM include those that are secondary, such as ammonium nitrate or secondary organic aerosol, which are usually more regional in nature, and those that are primary, such as black carbon from diesel truck combustion, which can be highly localized. For the latter, there is evidence of significant spatial gradients in traffic-related air pollution, such as elemental carbon PM from diesel vehicles, in the order of $100 \mathrm{~s}$ to $1000 \mathrm{~s}$ of meters from the road [15]. The inability to capture this small-scale variability is a concern in local- and community-based studies because of the potential for misspecification of health effects due to exposure misclassification [16,17].

Obtaining near-true exposure estimates requires conducting personal monitoring to capture individual activities both indoors and outdoors. As this approach to exposure assessment is economically impractical and limiting when studying health effects of large populations, scientists rely on ambient measures such as concentrations from national and state monitoring networks in combination with other geographic data $[18,19]$ to estimate exposures. Unfortunately, monitoring sites are often sparsely located, particularly in suburban and rural locations of the U.S. and in parts of the world where air pollution monitoring is not routinely conducted.

Satellite observations of AOD to estimate PM exposures provide more complete spatial and temporal coverage than fixed monitoring sites [20-25], but the existing methods using AOD are still limited to the resolution of the instrument's aerosol product retrieval algorithm. Fortunately, the spatial resolutions of satellite aerosol products have improved dramatically since their inception. For example, the Moderate Resolution Imaging Spectroradiometer (MODIS) on the NASA Terra Earth Observing System (EOS) Terra Satellite now has an operational aerosol product (Collection 6, C6) at three kilometer resolution [26,27], that is a large reduction in spatial resolution from the original $10 \mathrm{~km}$ product. However, increased spatial resolution sometimes presents new challenges. The surface reflectance database approach used in MODIS Dark Target (DT) retrievals often leads to under-prediction of surface reflectance (and over-prediction of AOD) in urban areas for both C6 DT $10 \mathrm{~km}$ and $3 \mathrm{~km}$ resolution products. As a result, larger biases have been observed in the $3 \mathrm{~km}$ product due to noise in the surface reflectance computations from retention of bright pixels in the retrieval window which would be discarded at $10 \mathrm{~km}$ averaging [28]. The MODIS Deep Blue algorithm, while providing reasonable performance over desert and semi-desert regions, was sometimes found to be unsuccessful over urban and vegetated surfaces, especially where seasonal and inter-annual changes are significant [29]. Recently, the Multi-Angle Implementation of Atmospheric Correction (MAIAC) was developed to provide MODIS AOD at a one kilometer spatial resolution [30], but this product is not yet publicly available.

The Multiangle Imaging SpectroRadiometer (MISR) team at the Jet Propulsion Laboratory recently developed a $4.4 \mathrm{~km}$ product with AOD retrievals having improved correlation with surface measurements and less bias than the operational (Version 22) $17.6 \mathrm{~km}$ product [31], while retaining important desired attributes such as AOD fraction, shape and type [32,33]. MISR has nine pushbroom cameras that make observations from nine different viewing directions along the direction of satellite motion in four spectral bands, enabling more robust separation of the surface from atmospheric effects [34]. Although MISR has a narrow $400 \mathrm{~km}$ swath compared to the $2300 \mathrm{~km}$ swath of MODIS, 
studies have shown that MISR provides important constraints on the surface $\mathrm{PM}_{2.5}$ concentrations estimated using AOD observations from both MODIS and MISR, especially in Western USA where the surface can be bright [23,35].

Despite these improvements in aerosol remote sensing spatial resolution, there is often still a need to capture very small-scale spatial variability in PM exposure estimates, particularly when the goal is to provide location-specific exposure estimates for study subjects in a health effects analysis [7]. Some studies have supplemented satellite observations with data on roads, elevation, or land use to characterize small-scale spatial variation [10]. These techniques have generally not provided useful insight into spatial patterns in PM concentrations, despite evidence of sometimes significant variability in PM at distances smaller than one kilometer [15,36]. Spatial variability affects the accuracy of exposure estimates; assumptions regarding subgrid-scale spatial processes have been shown to impact statistical [37] and numerical air quality model results [38]. It is not well understood whether current gridded satellite aerosol products provide information at spatial resolutions that sufficiently capture variability needed for generating air pollution exposures for health effects studies.

In this study, measurements from an extremely unique, spatially dense sampling campaign were used to better understand the small-scale (or subgrid-scale) variability in $\mathrm{PM}_{2.5}$ and $\mathrm{PM}_{2.5-10}$ within $4.4 \mathrm{~km}$ MISR pixels over Southern California. To quantify variability, we assessed the subgrid variance, correlation, and spatial semivariance in these measured concentrations with respect to gridded $4.4 \mathrm{~km}$ MISR AOD-derived $\mathrm{PM}_{2.5}$ and $\mathrm{PM}_{2.5-10}$. This detailed characterization of the small-scale variability in PM concentrations in relation to gridded satellite observations provides insight into the importance of spatial scale when estimating exposures for use in health effects studies. Furthermore, it can help address whether current resolutions of existing satellite aerosol observations are sufficient, or whether data at finer spatial scales are needed.

\section{Materials and Methods}

The study region encompasses eight communities (Anaheim, Glendora, Long Beach, Mira Loma, Riverside, San Dimas, Santa Barbara and Upland) within Southern California (Figure 1). All data described below are for the 2008-2009 period.

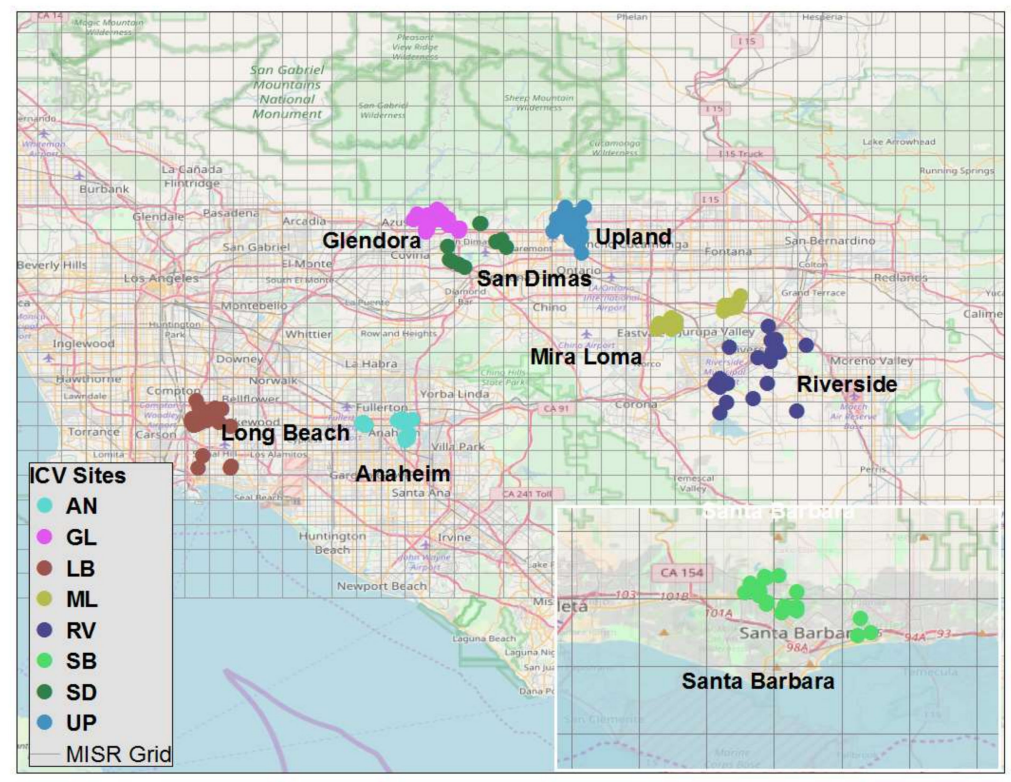

Figure 1. Study region showing Intra-Community Variability (ICV) monitoring sites and $4.4 \mathrm{~km}$ Multiangle Imaging SpectroRadiometer (MISR) grid over Southern California (Inset: Santa Barbara, CA). 


\subsection{Particulate Matter Concentrations}

The Intra-Community Variability (ICV) sampling campaign was conducted from November 2008 through December 2009 as part of the University of Southern California Children's Health Study (CHS) [15,39]. For eight Southern California communities, monitoring was conducted at the homes and schools of participating children to capture local, neighborhood, and regional variation in air pollution. Samplers were strategically placed within each community to capture spatial gradients in PM concentrations near different types of roads, as well as to measure background concentrations in residential areas at more centrally placed sites. Two Harvard Cascade Impactors [40], modified to have three cutpoints at $0.2 \mu \mathrm{m}, 2.5 \mu \mathrm{m}$ and $10 \mu \mathrm{m}$, were used to collect $\mathrm{PM}_{0.2}, \mathrm{PM}_{0.2-2.5}$ and $\mathrm{PM}_{2.5-10}$ samples. Typical Cascade Impactors have two cutpoints at $2.5 \mu \mathrm{m}$ and $10 \mu \mathrm{m}$. In this study, we represent the combined $<0.2 \mu \mathrm{m}$ and $0.2-2.5 \mu \mathrm{m}$ stages as $\mathrm{PM}_{2.5}$ (fine mode) and $\mathrm{PM}_{2.5-10}$ (coarse mode). Two consecutive 2-week samples were collected at up to 27 locations per community resulting in month-long integrated samples in the cool (Nov-Mar) and warm (May-Sept) seasons. Within a community, all ICV monitors had the same start and end dates; however, for logistical reasons, the start and end dates across the eight communities were different. In Southern California, the warm season averages about 13C warmer than the cool season, but this depends on the location in the Los Angeles basin: coastal regions such as Long Beach do not have as much seasonal variability as inland communities such as Riverside. The on-shore wind patterns are similar (winds from WSW during most days but with reduced hours per day in the cool season, along with longer and more pronounced nocturnal inversions.) These differences tend to increase the near-source impacts of primary pollution sources like traffic in the cool season, especially at night and early morning. Additional details regarding the ICV sampling methods and schedule can be found in Fruin et al. [15].

\subsection{MISR Aerosol Optical Depth and Derived Particulate Matter Concentrations}

The MISR instrument is onboard the NASA Terra Satellite, with a local overpass time of approximately 10:30 a.m. The $4.4 \mathrm{~km}$ MISR AOD were derived from high-resolution (275 m) MISR observations acquired over selected areas through the utilization of the Version 22 MISR operational aerosol retrieval algorithm [41]. In addition to AOD, the $4.4 \mathrm{~km}$ aerosol product contains five sub-fields representing AOD size fractions (small, medium and large), as well as shape (spherical and non-spherical). Additional details regarding MISR aerosol size partitioning can be found in Franklin et al. (2017) [12] and Dey and Di Girolamo (2010) [42]. In this study, we used the product of total column AOD and the size fractions (e.g., AOD $\times$ fraction_large $=$ AOD_large) to represent size-fractionated AOD. Due to MISR's narrow swath, it overpasses the same location approximately every 9 days.

In Franklin et al. [12], spatio-temporal models associating $4.4 \mathrm{~km}$ MISR size-fractionated AOD with national network monitoring concentrations of $\mathrm{PM}_{2.5}$ and $\mathrm{PM}_{10}$ from the Environmental Protection Agency (EPA), and weather station data from the National Oceanic and Atmospheric Administration (NOAA) over Southern California were developed. Adjustment of the AOD-PM relationship by meteorological parameters was done to account a for the vertical profile difference between AOD - a total column measure-and ground-level PM. We found that application of functional spatio-temporal regression models of AOD_small + AOD_medium, relative humidity, and wind speed provided the best estimates of ground-level $\mathrm{PM}_{2.5}$ concentrations $\left(\mathrm{R}^{2}=0.67\right)$. Similar regression models of AOD_large, dew point and wind speed provided the best estimates of ground-level $\mathrm{PM}_{10}$ concentrations $\left(\mathrm{R}^{2}=0.74\right)$. Additional details can be found in Franklin et al. [12].

For this study, we applied the models developed in Franklin et al. (2017) [12] to convert MISR AOD AOD_small + AOD_medium to $\mathrm{PM}_{2.5}$ and MISR AOD_large to $\mathrm{PM}_{10}$ concentrations over the region covering the eight communities shown in Figure 1. To relate to ICV coarse mode measurements $\left(\mathrm{PM}_{2.5-10}\right)$, we took the difference between MISR AOD-derived $\mathrm{PM}_{10}$ and $\mathrm{PM}_{2.5}$, generating comparable $\mathrm{PM}_{2.5-10}$ concentrations. 


\subsection{Data Processing}

A matching algorithm was developed to spatially and temporally link the MISR and ICV data as follows. First, the geocoded location of each ICV monitoring site was spatially matched with its coincident $4.4 \mathrm{~km}$ MISR grid cell. The start and end dates of each ICV monitoring site were then used to create a month long window within which MISR overpasses were retrieved. The MISR data that fell within the ICV time window were averaged. With an average of only two MISR overpasses per month, the monthly ICV PM sampled concentrations and the "pseudo-monthly" MISR data (AOD and modeled PM) were not reliably compared. Nevertheless, iteration of the spatial portion of the matching algorithm for every ICV monitoring site resulted in the matched dataset with which we were able to examine subgrid-scale variability in the measured PM concentrations. We defined subgrid variability as the variance in PM concentrations (units $\mu \mathrm{g}^{2} / \mathrm{m}^{6}$ ) from the ICV monitors that fell within a $4.4 \mathrm{~km}$ MISR grid cell. If only one ICV monitoring site was in a $4.4 \mathrm{~km}$ MISR grid cell, it was removed from the analysis of subgrid variance could not be calculated. For illustration, Figure 2 shows the $4.4 \mathrm{~km}$ MISR grid and the ICV monitoring sites in Riverside, CA that operated from 5 March 2009 to 2 April 2009. Details pertaining to the statistical definitions of subgrid and across-grid variance can be found in Section 2.4 .

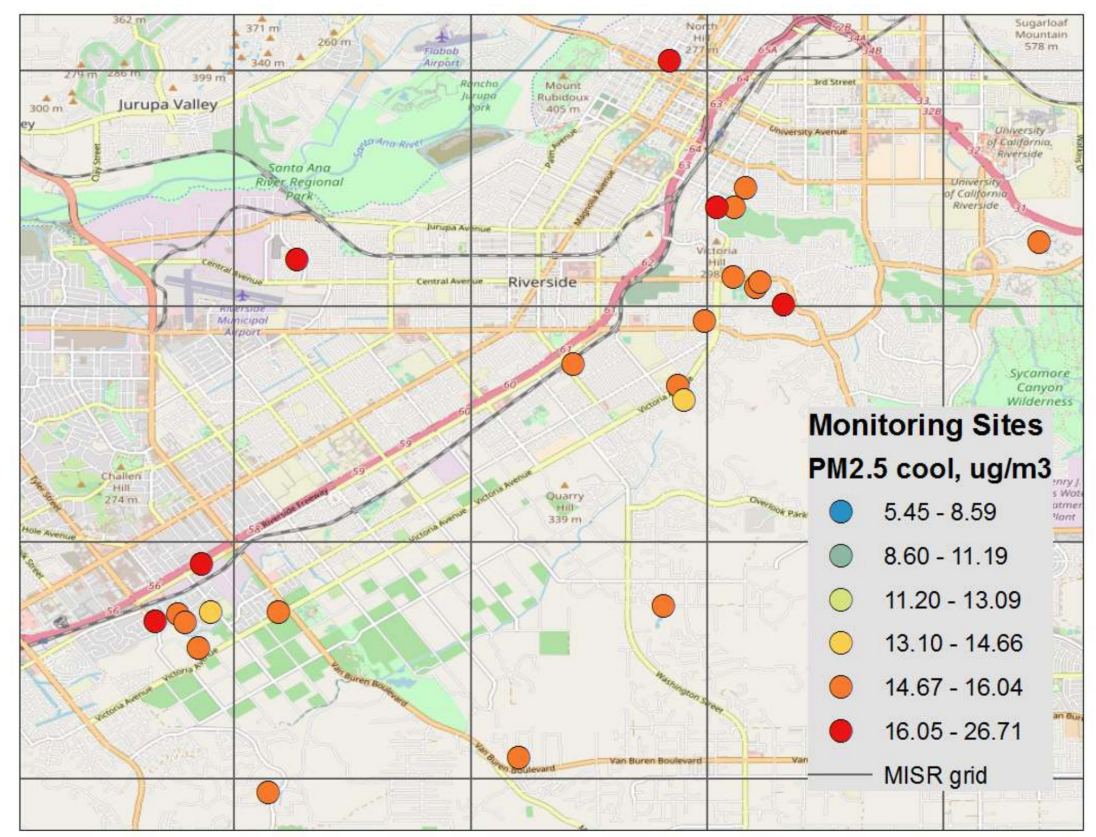

Figure 2. Map of Riverside, CA showing the $4.4 \mathrm{~km}$ MISR grid and the locations of ICV monitoring sites and the measured fine particulate matter $\left(\mathrm{PM}_{2.5}\right)$ concentrations $\left(\mu \mathrm{g} / \mathrm{m}^{3}\right)$ in the cool season, illustrating the matching algorithm for subgrid-scale analyses.

\subsection{Statistical Analyses}

Since all ICV monitors within a community operated according to the same start and end dates, temporal variability was controlled in our analyses.

To formally characterize subgrid-scale variability, we examined components of the variance using the within-group coefficient of variation $\left(\mathrm{CV}_{\mathrm{WG}}\right)$ and intra-class correlation (ICC) where "class" (group) is a $4.4 \mathrm{~km}$ MISR grid cell. The $\mathrm{CV}_{\mathrm{WG}}$ (often called the within-subject coefficient of variation) describes the relative amount of within-group variability to the within-group mean. The ICC describes the similarity in values within a group. Variance components were estimated using the random effects model:

$$
[P M]_{i j}=\mu+\alpha_{j}+\varepsilon_{i j}
$$


where $[P M]$ represents the $\mathrm{PM}_{2.5}$ or $\mathrm{PM}_{2.5-10}$ concentration measured at ICV monitor $i$ within MISR $4.4 \mathrm{~km}$ grid cell $j, \mu$ is the overall mean concentration, $\alpha_{j} \sim N\left(0, \sigma_{\alpha}^{2}\right)$ is the grid cell random effect having across-grid variance $\sigma_{\alpha}^{2}$, and $\varepsilon_{i j} \sim N\left(0, \sigma^{2}\right)$ is the residual (unexplained variance) having within-grid (i.e., subgrid) variance $\sigma^{2}$. Together, this results in $[P M]_{i j} \sim N\left(\mu, \sigma_{\alpha}^{2}+\sigma^{2}\right)$. Given this random effects model, the $\mathrm{CV}_{\text {WG }}$ was calculated by $\frac{\sigma}{\mu}$ and after multiplying by 100 represents the amount of within-grid variance as a percentage of the mean. The ICC was calculated by $\frac{\sigma_{\alpha}^{2}}{\sigma_{\alpha}^{2}+\sigma^{2}}$ and represents the fraction of the total variance that is accounted for by variation across grid cells. In other words, an ICC value of 0 indicates all of the variability in ICV PM concentrations is attributed to within-grid variance, and an ICC value of 1 indicates that none of the variability in ICV PM is attributed to within-grid variance.

To gain a better understanding of the spatial variability in the data we used the empirical semivariogram, a standard geostatistical measure of variance as a function of distance. We applied the Cressie-Hawkins robust estimator [43] of the semivariance:

$$
\hat{\gamma}(h)=\frac{1}{2|N(h)|} \frac{\left(\sum_{N(h) \in i, j}\left|Z\left(s_{i}\right)-Z\left(s_{j}\right)\right|^{1 / 2}\right)^{4}}{0.457+0.494 / N(h)},
$$

where $h$ is the distance bin $(\mathrm{km}), N(h)$ is the number of observations within distance bin $h, Z\left(s_{i}\right)$ is the PM concentration at location $s_{i}$ and $Z\left(s_{j}\right)$ is the concentration at location $s_{j}$. The semivariance obtained from Equation (2) is half the variance of the differences between all possible PM concentrations that are at a distance of $h$ units apart, for $h$ fixed in $N$ distance bins. We visualized the semivariograms as boxplots for each distance bin, and additionally tested the statistical difference between the concentrations in each bin by paired $t$-tests with Bonferroni adjustment for multiple comparisons. The semivariance has units of variance, so in the case of PM concentrations, the units are $\mu \mathrm{g}^{2} / \mathrm{m}^{6}$.

\section{Results}

Community-specific summary statistics describing the number of monitors matched with $4.4 \mathrm{~km}$ MISR grid cells, and the PM concentrations measured at the ICV monitoring locations are shown in Table 1.

Table 1. Summary statistics of matched MISR-ICV data.

\begin{tabular}{|c|c|c|c|c|c|c|}
\hline Community & $\operatorname{ICV~N} *$ & $\begin{array}{l}\text { ICV in MISR } \\
\text { Grid } N^{*}\end{array}$ & $\begin{array}{c}\text { ICV } \text { PM }_{2.5} * * \\
\text { Warm } \\
\text { Mean (s.d.) }\end{array}$ & $\begin{array}{c}\text { ICV } \mathrm{PM}_{2.5} \\
\text { Cool } \\
\text { Mean (s.d.) }\end{array}$ & $\begin{array}{c}\text { ICV PM } \text { PM.5-10 } \\
\text { Warm } \\
\text { Mean (s.d.) }\end{array}$ & $\begin{array}{c}\text { ICV PM } \text { PM.5-10 } \\
\text { Cool } \\
\text { Mean (s.d.) }\end{array}$ \\
\hline Anaheim & 23 & 8 & 15.9 (1.47) & $13.8(1.04)$ & $14.8(3.31)$ & $11.3(0.95)$ \\
\hline Glendora & 27 & 8 & $15.3(2.09)$ & $11.0(1.68)$ & $10.1(1.01)$ & $8.85(0.86)$ \\
\hline Long Beach & 26 & 4 & $15.0(1.55)$ & $13.4(1.0)$ & $14.9(3.83)$ & $12.6(1.61)$ \\
\hline Mira Loma & 25 & 6 & $19.3(1.59)$ & $24.3(3.2)$ & $19.2(6.00)$ & $20.5(4.28)$ \\
\hline Riverside & 23 & 6 & 14.5 (1.37) & $15.8(0.86)$ & $17.0(3.06)$ & $13.0(1.33)$ \\
\hline San Dimas & 25 & 6 & $14.0(1.48)$ & $15.5(1.37)$ & $13.1(1.09)$ & $12.6(1.43)$ \\
\hline $\begin{array}{l}\text { Santa } \\
\text { Barbara }\end{array}$ & 26 & 9 & $11.9(1.09)$ & $11.0(1.98)$ & $10.3(2.71)$ & $11.3(1.64)$ \\
\hline Upland & 24 & 8 & $16.9(0.84)$ & $7.14(0.82)$ & $14.3(1.25)$ & $4.45(0.71)$ \\
\hline Overall & 199 & 7 & $15.0(2.61)$ & $14.0(4.92)$ & $13.8(4.31)$ & $11.9(4.54)$ \\
\hline
\end{tabular}

* Across season mean N: there were in total 204 total ICV monitoring sites in the warm season and 192 in the cool season; ${ }^{* *} \mathrm{PM}_{2.5}$ and $\mathrm{PM}_{2.5-10}$ concentrations in $\mu \mathrm{g} / \mathrm{m}^{3}$.

Across seasons, the mean number of ICV monitors within a MISR grid cell was seven, with as few as four in Long Beach and as many as nine in Santa Barbara. Community mean ICV $\mathrm{PM}_{2.5}$ concentrations were higher in the warm season except for in the Inland Empire communities of Mira Loma, Riverside and San Dimas. The largest seasonal gradients occurred in Upland, where concentrations were strikingly low in the cool season $\left(7.14\right.$, s.d. $\left.0.82 \mu \mathrm{g} / \mathrm{m}^{3}\right)$. The $\mathrm{PM}_{2.5-10}$ 
concentrations were almost all higher in the warm season, with the exception of Mira Loma. The variability within each community tended to be greater for $\mathrm{PM}_{2.5-10}$ than $\mathrm{PM}_{2.5}$, as indicated by the standard deviations in Table 1.

\subsection{Assessment of Subgrid Variability}

There were distinct seasonal differences in the subgrid variability in $\mathrm{PM}_{2.5}$. Across all ICV sites and communities, the variance in ICV PM 2.5 was substantially smaller in the warm $\left(6.82 \mu \mathrm{g}^{2} / \mathrm{m}^{6}\right)$ than cool $\left(24.5 \mu \mathrm{g}^{2} / \mathrm{m}^{6}\right)$ season. In the warm season, the average subgrid variance in ICV PM $2.5 \mathrm{Was}$ $2.03 \mu \mathrm{g}^{2} / \mathrm{m}^{6}$, the $C V_{\mathrm{WG}}$ was $9.6 \%$, and the ICC was 0.69 . In cool season, the average subgrid variance of $\mathrm{PM}_{2.5}$ was slightly larger at $2.45 \mu \mathrm{g}^{2} / \mathrm{m}^{6}$, the $C V_{\mathrm{WG}}$ was similar to warm $(10 \%)$, but the ICC was 0.90 , indicating that there was greater variability in ICV concentrations across the MISR grid cells than within grid cells. This pattern was corroborated by the much larger variance in cool season $\mathrm{PM}_{2.5}$ across sites and communities.

For $\mathrm{PM}_{2.5-10}$, the variance across all ICV sites and communities was similar in warm $\left(18.6 \mu \mathrm{g}^{2} / \mathrm{m}^{6}\right)$ and cool seasons $\left(20.6 \mu \mathrm{g}^{2} / \mathrm{m}^{6}\right)$. The average subgrid variance in ICV PM $2.5-10$ in the warm season was $8.90 \mu \mathrm{g}^{2} / \mathrm{m}^{6}$, the $C V_{\mathrm{WG}}$ was $21 \%$, and the ICC was 0.57 . The large $C V_{\mathrm{WG}}$ indicated greater subgrid variability relative to the subgrid mean in warm months. In the cool season, the average subgrid variance was $3.28 \mu^{2} / \mathrm{m}^{6}$, the $C_{\text {WG }}$ was $14 \%$, and the ICC was 0.91 . Again, the large ICC indicated that there was greater variability in ICV concentrations across the MISR grid cells than within grid cells in the cool season. In general we noted larger $C V_{W G}$ and average subgrid variance for $P_{2.5-10}$ across seasons, indicating greater small-scale variability in larger particles than smaller particles.

\subsection{Assessment of Spatial Variance}

The spatial variability in the ICV data using empirical semivariograms (Equation (2)) binned into kilometer increments suggested that there was a spatial pattern in the ICV PM data, and that this pattern differed by size fraction and season (Figure 3). For ICV monitoring locations within distances representative of the MISR grid resolution (less than five kilometers in Figure 3), the median semivariance of $\mathrm{PM}_{2.5}$ did not vary substantially, ranging from $0.99-1.13 \mu \mathrm{g}^{2} / \mathrm{m}^{6}$ in the warm season, and from $0.93-1.40 \mathrm{\mu g}^{2} / \mathrm{m}^{6}$ in the cool season. We noted that the semivariance was not as large, nor did it increase with distance (greater than five kilometers) as rapidly in the warm season, but in the cool season we saw a more traditional spatial pattern whereas distances got larger (greater than five kilometers), the median semivariance increased. The latter is indicative of the common phenomenon that at further distances, observations become less similar. Similar patterns were observed in the semivariograms for $\mathrm{PM}_{2.5-10}$, where semivariance below five kilometers ranged from $1.12-1.34 \mu^{2} / \mathrm{m}^{6}$ in the warm season and $0.86-1.31 \mu \mathrm{g}^{2} / \mathrm{m}^{6}$ in the cool season. In the warm season the $\mathrm{PM}_{2.5-10}$ semivariance did not have the typical increase with distance that was more distinct in the cool season. 


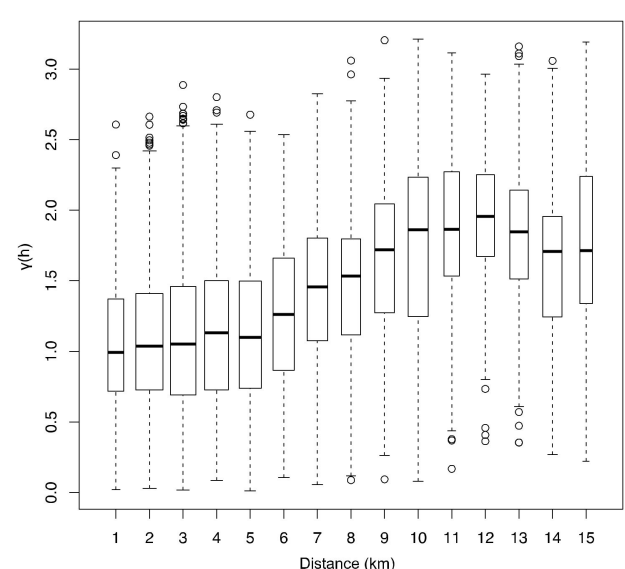

(a)

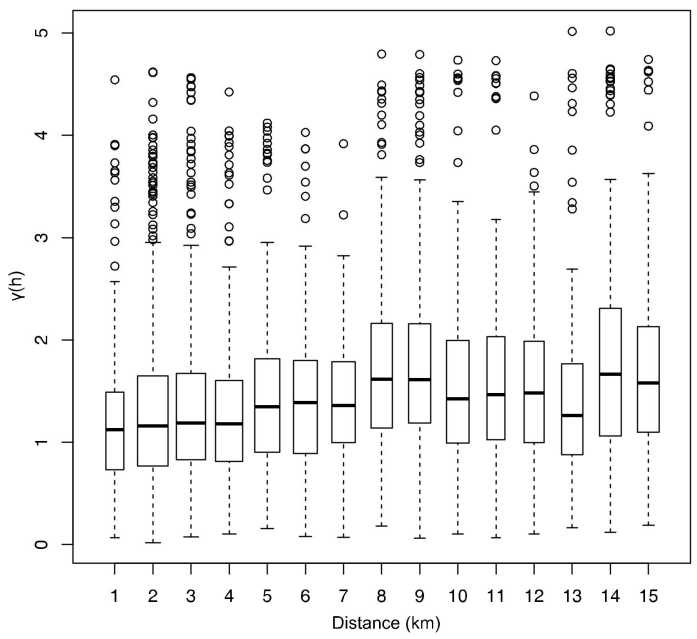

(c)

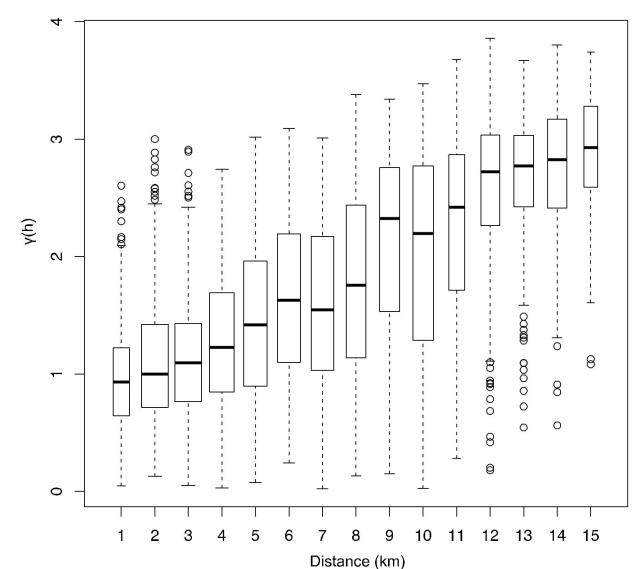

(b)

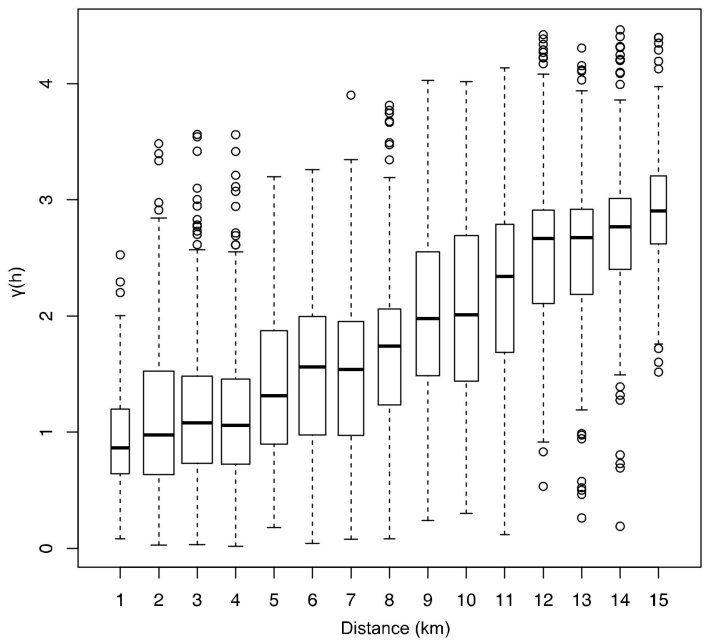

(d)

Figure 3. Boxplot empirical semivariograms showing distance (h in $\mathrm{km}$ ) versus spatial semivariance $\gamma(h)$ for (a) $\mathrm{PM}_{2.5}$ warm season; (b) $\mathrm{PM}_{2.5}$ cool season; (c) $\mathrm{PM}_{2.5-10}$ warm season; (d) $\mathrm{PM}_{2.5-10}$ cool season. Solid vertical lines denote median, edges of box denote the 25th and 75th percentiles, and the dashed line whiskers denote $\pm 1.5 \times \mathrm{IQR}$.

Adjusted pairwise comparisons of the data in each semivariogram bin indicated that there was a statistically significant $(p<0.001)$ difference in warm season $\mathrm{PM}_{2.5}$ semivariance in the seven kilometer and smaller bins compared to the semivariance at larger scales. For $\mathrm{PM}_{2.5-10}$ in the warm season, there was a statistically significant difference between the semivariance in the eight kilometer bin and those seven kilometers and less, but there was not a significant difference in any of the bins between one and seven kilometers. In the cool season we observed greater spatial heterogeneity, which was corroborated by a statistically significant difference in the semivariance between the five kilometer bin and the smaller bins $(p<0.001)$ in both $\mathrm{PM}_{2.5}$ and $\mathrm{PM}_{2.5-10}$ in the cool season.

Zooming into MISR subgrid-scale distances $(<4.4 \mathrm{~km})$, for $\mathrm{PM}_{2.5}$ in the cool season the empirical semivariogram (Figure 4) shows smaller semivariance at very small distances. At $240 \mathrm{~m}$ the median semivariance was $0.62 \mu \mathrm{g}^{2} / \mathrm{m}^{6}$, but it rose quickly at $488 \mathrm{~m}$ where it was $0.96 \mu \mathrm{g}^{2} / \mathrm{m}^{6}$, and then by $730 \mathrm{~m}$ it was $1.02 \mu \mathrm{g}^{2} / \mathrm{m}^{6}$, which was approximately equivalent to what was observed at scales of one to five kilometers. However, the apparent small-scale spatial variance at $240 \mathrm{~m}$ was not statistically different than the larger distance bins by the multiple comparisons test. Figure 4 also shows evidence of subgrid-scale spatial pattern for cool season $\mathrm{PM}_{2.5-10}$. At $240 \mathrm{~m}$ the median semivariance was $0.72 \mu \mathrm{g}^{2} / \mathrm{m}^{6}$, at $488 \mathrm{~m}$ it was $0.75 \mu \mathrm{g}^{2} / \mathrm{m}^{6}$ and at $730 \mathrm{~m}$ it was $1.04 \mu \mathrm{g}^{2} / \mathrm{m}^{6}$. Multiple comparisons 
identified a statistically significant difference between the $480 \mathrm{~m}$ bin and the $730 \mathrm{~m}$ bin (and larger), indicating small-scale subgrid variability differences. The semivariance in the $240 \mathrm{~m}$ bin was not statistically different from the $480 \mathrm{~m}$ bin.

As neither $\mathrm{PM}_{2.5}$ nor $\mathrm{PM}_{2.5-10}$ in the warm season showed discernible spatial heterogeneity below seven kilometers, we did not anticipate significant small-scale spatial variability. A check of pairwise comparisons in the warm season subgrid spatial analysis confirmed this, as none of the $<4.4 \mathrm{~km}$ binned semivariances were statistically different than another.

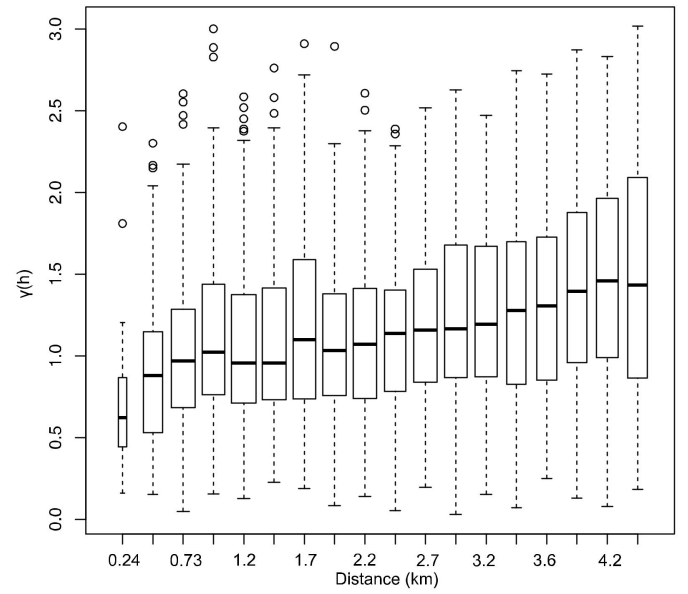

(a)

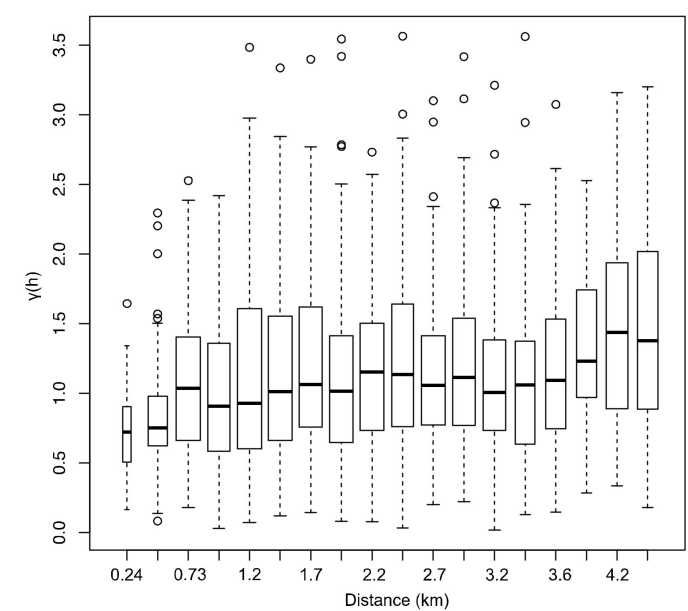

(b)

Figure 4. Boxplot empirical semivariograms showing distance ( $\mathrm{h}$ in $\mathrm{km}$ ) versus spatial semivariance $\gamma(h)$ for subgrid $\left(<4.4 \mathrm{~km}\right.$ ) variability in (a) $\mathrm{PM}_{2.5}$ cool season; (b) $\mathrm{PM}_{2.5-10}$ cool season. Solid vertical lines denote median, edges of box denote the 25 th and 75 th percentiles, and the dashed line whiskers denote $\pm 1.5 \times$ IQR.

\section{Discussion}

Recent advances in computational techniques to generate satellite aerosol products at finer spatial resolutions have proven to be extremely valuable to the public health and environmental science communities. However, any gridded data, including remote sensing observations, have the limitation of being constrained by the resolution of the instrument and data-generating algorithm. Implicit in this limitation is that the value in each grid cell, whether it is AOD or a predicted PM concentration, is spatially constant, and any subgrid variation is random. We attempted to characterize this subgrid variation using PM concentrations from a unique high-density air pollution sampling campaign over Southern California linked with the new $4.4 \mathrm{~km}$ MISR aerosol product.

We found distinct seasonal differences in our characterization of subgrid and across-grid variance. For $\mathrm{PM}_{2.5}$, relative to the subgrid variance the across-grid variance was small the in warm season compared to the cool season. The same phenomenon was previously shown [15], where coefficients of variation within the eight Southern California communities were smallest for $\mathrm{PM}_{2.5}$ in the warm season. This can be attributed to secondary formation of $\mathrm{PM}_{2.5}$, resulting in a more uniform (i.e., regional) distribution of concentrations over the area.

For the coarse fraction, we also found seasonal differences in subgrid and across-grid variance, where the warm season showed smaller variability across the MISR grids than within grids, and in the cool season the opposite phenomenon was observed. The subgrid variability in $\mathrm{PM}_{2.5-10}$ captured by the ICV monitors was likely dominated by non-tailpipe emissions such as brake wear, tire wear, and re-suspended road dust. Observed seasonal differences were likely due to the added contribution of wind-blown dust, a large portion of $\mathrm{PM}_{10}$, which is transported from desert areas by southwesterly summer winds. This, coupled with meteorological conditions, tends to lead to higher overall $\mathrm{PM}_{2.5-10}$ 
concentrations in the warm season [44]. In the cool season the subgrid variability can be attributed more directly to localized traffic sources. A similar phenomenon was noted in a study of 20 European cities [14], where greater spatial variability in $\mathrm{PM}_{\text {coarse }}$ relative to background concentrations was attributed to non-tailpipe traffic emissions.

The assessment of spatial variability in the measured concentrations revealed several enlightening properties. If examined on the kilometer scale, both $\mathrm{PM}_{2.5}$ and $\mathrm{PM}_{2.5-10}$ exhibited similar patterns; the magnitude of spatial variability was approximately the same below five kilometers. This was more pronounced in the warm season, where the spatial variability relatively constant at seven kilometers and below. This indicated that there would not likely be a significant amount of spatial information gained for satellite observations made at less than $4.4 \mathrm{~km}$ (MISR), such as three kilometer (MODIS), or one kilometer (MAIAC) resolution. However, when we zoomed in to examine small, subgrid-scale spatial variability in the cool season, we noted that at there was a breakpoint at $488 \mathrm{~m}$ with a notable difference in the semivariance in $\mathrm{PM}_{2.5}$ and $\mathrm{PM}_{2.5-10}$ concentrations than at larger scales. This indicated that satellite observations from grids of $1-4.4 \mathrm{~km}$ could be averaging out spatial information that is discernable only at sub-kilometer scales. In a statistical comparisons test of the semivariance at these distance scales, we only found indication of significant differences at $480 \mathrm{~m}$ and below for $\mathrm{PM}_{2.5-10}$. Thus, grid resolutions of around 250-500 m could capture variability related to near-road gradients traffic emission gradients or other highly localized point sources such as resuspended road dust, which is mostly present in the coarse mode. Interestingly, this sub-kilometer spatial variability was only seen in the cool season. As discussed above, this is likely due to a greater amount of regional sources in both $\mathrm{PM}_{2.5}$ (secondary formation) and $\mathrm{PM}_{10}$ (wind-blown dust) that contribute to more uniform concentrations at small spatial scales in the warm season. It is also possible that the seasonal spatial differences are attributable to the chemical components of the PM mass [45].

Being able to capture highly localized variability in PM concentrations may have a significant impact on health effects studies, particularly those that involve residential study subject information. Previous studies have shown health outcomes including increased asthma prevalence and reduced lung function growth associated with residential proximity to busy roads $(<75 \mathrm{~m})$ and freeways $(<500 \mathrm{~m})[46]$. Residential locations between $100 \mathrm{~m}$ and $200 \mathrm{~m}$ from roads were also found to be associated with elevated exhaled nitric oxide (FeNO), a marker of airway inflammation [47]. However, there have been inconsistencies in reported associations between residential proximity to roads and health outcomes [48] suggesting roadway proximity may not be a sufficiently adequate proxy for air pollution exposure. Capturing spatial gradients in PM concentrations through the use of satellite observations could help overcome the issue of having to use roadway proxies to characterize exposures. However, limitations in using satellite AOD to provide adequate spatial variability in PM concentrations for health effects studies have been noted [49]. A recent examination of several exposure models found that health effects estimated based on models integrating ground-based information and satellite AOD to produce $\mathrm{PM}_{2.5}$ estimates at a $30 \mathrm{~m}$ resolution were larger and had smaller standard errors [50]. Thus, a hybrid approach incorporating information on spatial gradients from roads is possibly the best approach to capture subgrid-scale gradients in satellite observations, particularly when estimating PM exposures that are also temporally resolved.

The primary limitation of this study is that we were unable to meaningfully compare the previously derived MISR PM concentrations with the measured ICV concentrations. An average of only two MISR observations per month did not adequately represent the integrated month long ICV samples. In a future study, daily AOD from three kilometer MODIS or one kilometer MAIAC could be harnessed and matched to the monthly ICV sampling data, as they would provide a more representative average for comparison. Another potential limitation is in the ICV sampling design, where within a $4.4 \mathrm{~km}$ MISR grid cell we observed that in some communities monitors clustered near roads, not necessarily providing a uniform spatial representation of the subgrid variability. 


\section{Conclusions}

Overall, we found the presence of seasonal differences in spatial variability in $\mathrm{PM}_{2.5}$ and $\mathrm{PM}_{2.5-10}$ with respect to the $4.4 \mathrm{~km}$ MISR grid. Spatial variability in PM concentrations was not statistically significantly different for distances below five kilometers when examined on the kilometer scale, and there was only some evidence of spatial differences in the cool season at distances on the order of 250-500 $\mathrm{m}$ for $\mathrm{PM}_{2.5-10}$, likely due to small-scale sources such as resuspended road dust from traffic. Our findings can be generalized beyond MISR to other satellite aerosol products and suggest that spatial variability on the sub-five kilometer scale is likely sufficient for most applications, but that variability on the scale of hundreds of meters may need to be taken into account in specific situations such as when estimating seasonal traffic-related PM exposures from satellite observations.

Acknowledgments: This study was funded by the Jet Propulsion Laboratory grant NNN12AA01C. Portions of this work were performed at the Jet Propulsion Laboratory, California Institute of Technology, under a contract with the National Aeronautics and Space Administration.

Author Contributions: Meredith Franklin conceived and conducted the data analyses and wrote the majority of the manuscript. Olga Kalashnikova contributed to writing about the interpretation of the $4.4 \mathrm{~km}$ MISR data. Michael Garay produced the $4.4 \mathrm{~km}$ MISR data. Scott Fruin produced the data on the ICV measurements and assisted in in their interpretation.

Conflicts of Interest: The authors declare no conflict of interest.

\section{References}

1. Pope, A.C.; Dockery, D.W. Health effects of fine particulate air pollution: Lines that connect. J. Air Waste Manage. Assoc. 2006, 56, 709-742. [CrossRef]

2. Franklin, M.; Zeka, A.; Schwartz, J. Association between $\mathrm{PM}_{2.5}$ and all-cause and specific-cause mortality in 27 US communities. J. Expo. Sci. Environ. Epidemiol. 2007, 17, 279-287. [CrossRef] [PubMed]

3. Brook, R.D.; Rajagopalan, S.; Pope, C.A.; Brook, J.R.; Bhatnagar, A.; Diez-Roux, A.V.; Holguin, F.; Hong, Y.; Luepker, R.V.; Mittleman, M.A.; et al. Particulate matter air pollution and cardiovascular disease: An update to the scientific statement from the American Heart Association. Circulation 2010, 121, 2331-2378. [CrossRef] [PubMed]

4. Tétreault, L.; Doucet, M.; Gamache, P.; Fournier, M.; Brand, A.; Kosatsky, T. Childhood exposure to ambient air pollutants and the onset of asthma: An administrative cohort study in Québec. Environ. Health Perspect. 2016, 1276, 1276-1283. [CrossRef] [PubMed]

5. Brauer, M.; Hoek, G.; Smit, H.A.; de Jongste, J.C.; Gerritsen, J.; Postma, D.S.; Kerkhof, M.; Brunekreef, B. Air pollution and development of asthma, allergy and infections in a birth cohort. Eur. Respir. J. 2007, 29, 879-888. [CrossRef] [PubMed]

6. Urman, R.; McConnell, R.; Islam, T.; Avol, E.L.; Lurmann, F.W.; Vora, H.; Linn, W.S.; Rappaport, E.B.; Gilliland, F.D.; Gauderman, W.J. Associations of children's lung function with ambient air pollution: Joint effects of regional and near-roadway pollutants. Thorax 2014, 69, 540-547. [CrossRef] [PubMed]

7. Franklin, M.; Vora, H.; Avol, E.; McConnell, R.; Lurmann, F.; Liu, F.; Penfold, B.; Berhane, K.; Gilliland, F.; Gauderman, W.J. Predictors of intra-community variation in air quality. J. Expo. Sci. Environ. Epidemiol. 2012, 22, 135-147. [CrossRef] [PubMed]

8. Fuentes, M.; Raftery, A.E. Model evaluation and spatial interpolation by Bayesian combination of observations with outputs from numerical models. Biometrics 2005, 61, 36-45. [CrossRef] [PubMed]

9. Isakov, V.; Irwin, J.S.; Ching, J. Using CMAQ for exposure modeling and characterizing the subgrid variability exposure estimates. J. Appl. Meteorol. Climatol. 2007, 46, 1354-1371. [CrossRef]

10. Liu, Y.; Paciorek, C.J.; Koutrakis, P. Estimating regional spatial and temporal variability of $\mathrm{PM}_{2.5}$ concentrations using satellite data, meteorology, and land use information. Environ. Health Perspect. 2009, 117, 886-892. [CrossRef] [PubMed]

11. Van Donkelaar, A.; Martin, R.V.; Brauer, M.; Boys, B.L. Use of satellite observations for long-term exposure assessment of global concentrations of fine particulate matter. Environ. Health Perspect. 2015, 123, 135-143. [CrossRef] [PubMed] 
12. Franklin, M.; Kalashnikova, O.V.; Garay, M.J. Size-resolved particulate matter concentrations derived from $4.4 \mathrm{~km}$ resolution size-fractionated Multi-angle Imaging SpectroRadiometer (MISR) aerosol optical depth over Southern California. Remote Sens. Environ. 2017, 196, 312-323. [CrossRef]

13. Jerrett, M.; Arain, A.; Kanaroglou, P.; Beckerman, B.; Potoglou, D.; Sahsuvaroglu, T.; Morrison, J.; Giovis, C. A review and evaluation of intraurban air pollution exposure models. J. Expo. Anal. Environ. Epidemiol. 2005, 15, 185-204. [CrossRef] [PubMed]

14. Eeftens, M.; Tsai, M.Y.; Ampe, C.; Anwander, B.; Beelen, R.; Bellander, T.; Cesaroni, G.; Cirach, M.; Cyrys, J.; de Hoogh, K.; et al. Spatial variation of $\mathrm{PM}_{2.5}, \mathrm{PM}_{10}, \mathrm{PM}_{2.5}$ absorbance and PMcoarse concentrations between and within 20 European study areas and the relationship with $\mathrm{NO}_{2}$-Results of the ESCAPE project. Atmos. Environ. 2012, 62, 303-317. [CrossRef]

15. Fruin, S.; Urman, R.; Lurmann, F.; McConnell, R.; Gauderman, J.; Rappaport, E.; Franklin, M.; Gilliland, F.D.; Shafer, M.; Gorski, P.; et al. Spatial variation in particulate matter components over a large urban area. Atmos. Environ. 2014, 83, 211-219. [CrossRef] [PubMed]

16. Wilson, J.G.; Kingham, S.; Pearce, J.; Sturman, A.P. A review of intraurban variations in particulate air pollution: Implications for epidemiological research. Atmos. Environ. 2005, 39, 6444-6462. [CrossRef]

17. Jerrett, M.; Burnett, R.T.; Ma, R.; Pope, C.A., 3rd; Krewski, D.; Newbold, K.B.; Thurston, G.; Shi, Y.; Finkelstein, N.; Calle, E.E.; et al. Spatial analysis of air pollution and mortality in Los Angeles. Epidemiology 2005, 16, 727-736. [CrossRef] [PubMed]

18. Sampson, P.D.; Richards, M.; Szpiro, A.A.; Bergen, S.; Sheppard, L.; Larson, T.V.; Kaufman, J.D. A regionalized national universal kriging model using Partial Least Squares regression for estimating annual $\mathrm{PM}_{2.5}$ concentrations in epidemiology. Atmos. Environ. 2013, 75, 383-392. [CrossRef] [PubMed]

19. Paciorek, C.J.; Yanosky, J.D.; Puett, R.C.; Laden, F.; Suh, H.H. Practical large-scale spatio-temporal modeling of particulate matter concentrations. Ann. Appl. Stat. 2009, 3, 370-397. [CrossRef]

20. Brauer, M.; Amann, M.; Burnett, R.T.; Cohen, A.; Dentener, F.; Ezzati, M.; Henderson, S.B.; Krzyzanowski, M.; Martin, R.V; Van Dingenen, R.; et al. Exposure assessment for estimation of the global burden of disease attributable to outdoor air pollution. Environ. Sci. Technol. 2012, 46, 652-660. [CrossRef] [PubMed]

21. De Sherbinin, A.; Levy, M.A.; Zell, E.; Weber, S.; Jaiteh, M. Using satellite data to develop environmental indicators. Environ. Res. Lett. 2014, 9, 84013. [CrossRef]

22. Liu, Y.; Franklin, M.; Kahn, R.; Koutrakis, P. Using aerosol optical thickness to predict ground-level $\mathrm{PM}_{2.5}$ concentrations in the St. Louis area: A comparison between MISR and MODIS. Remote Sens. Environ. 2007, 107, 33-44. [CrossRef]

23. Van Donkelaar, A.; Martin, R.V.; Park, R.J. Estimating ground-level $\mathrm{PM}_{2.5}$ using aerosol optical depth determined from satellite remote sensing. J. Geophys. Res. Atmos. 2006, 111, 1-10. [CrossRef]

24. Van Donkelaar, A.; Martin, R.V.; Spurr, R.J.D.; Drury, E.; Remer, L.A.; Levy, R.C.; Wang, J. Optimal estimation for global ground-level fine particulate matter concentrations. J. Geophys. Res. Atmos. 2013, 118, 5621-5636. [CrossRef]

25. Weber, S.; Engel-Cox, J.; Hoff, R.; Parados, A.; Zhang, H. An improved method for estimating surface fine particle concentrations using seasonally adjusted satellite aerosol optical depth. J. Air Waste Manag. Assoc. 2010, 60, 574-585. [CrossRef] [PubMed]

26. Levy, R.C.; Mattoo, S.; Munchak, L.A.; Remer, L.A.; Sayer, A.M.; Patadia, F.; Hsu, N.C. The Collection 6 MODIS aerosol products over land and ocean. Atmos. Meas. Tech. 2013, 6, 2989-3034. [CrossRef]

27. Remer, L.A.; Mattoo, S.; Levy, R.C.; Munchak, L.A. MODIS 3 km aerosol product: Algorithm and global perspective. Atmos. Meas. Tech. 2013, 6, 1829-1844. [CrossRef]

28. Nichol, J.E.; Bilal, M. Validation of MODIS $3 \mathrm{~km}$ resolution aerosol optical depth retrievals over Asia. Remote Sens. 2016, 8, 328. [CrossRef]

29. Hsu, N.C.; Jeong, M.J.; Bettenhausen, C.; Sayer, A.M.; Hansell, R.; Seftor, C.S.; Huang, J.; Tsay, S.C. Enhanced Deep Blue aerosol retrieval algorithm: The second generation. J. Geophys. Res. Atmos. 2013, 118, 9296-9315. [CrossRef]

30. Lyapustin, A.; Wang, Y.; Laszlo, I.; Kahn, R.; Korkin, S.; Remer, L.; Levy, R.; Reid, J.S. Multiangle implementation of atmospheric correction (MAIAC): 2. Aerosol algorithm. J. Geophys. Res. Atmos. 2011, 116, 1-15. [CrossRef] 
31. Garay, M.J.; Kalashnikova, O.V.; Bull, M.A. Development and assessment of a high spatial resolution (4.4 km) MISR aerosol product using AERONET-DRAGON Data. Atmos. Chem. Phys. Discuss. 2016, 17, 18-28. [CrossRef]

32. Diner, D.J.; Beckert, J.C.; Bothwell, G.W.; Rodriguez, J.I. Performance of the MISR instrument during its first 20 months in earth orbit. IEEE Trans. Geosci. Remote Sens. 2002, 40, 1449-1466. [CrossRef]

33. Kahn, R.A.; Gaitley, B.J. An analysis of global aerosol type as retrieved by MISR. J. Geophys. Res. Atmos. 2015, 120, 4248-4281. [CrossRef]

34. Kahn, R.A.; Gaitley, B.J.; Martonchik, J.V; Diner, D.J.; Crean, K.A. Multiangle Imaging Spectroradiometer (MISR) global aerosol optical depth validation based on 2 years of coincident Aerosol Robotic Network (AERONET ) observations. J. Geophys. Res. 2005, 110, 1-16. [CrossRef]

35. Van Donkelaar, A.; Martin, R.V.; Brauer, M.; Kahn, R.; Levy, R.; Verduzco, C.; Villeneuve, P.J. Global estimates of ambient fine particulate matter concentrations from satellite-based aerosol optical depth: Development and application. Environ. Health Perspect. 2010, 118, 847-855. [CrossRef] [PubMed]

36. Weijers, E.P.; Khlystov, A.Y.; Kos, G.P.A.; Erisman, J.W. Variability of particulate matter concentrations along roads and motorways determined by a moving measurement unit. Atmos. Environ. 2004, 38, 2993-3002. [CrossRef]

37. Paciorek, C.J. Combining spatial information sources while accounting for systematic errors in proxies. J.R. Stat. Soc. 2011, 61, 429-451. [CrossRef]

38. Ching, J.; Majeed, M.A. An approach to characterize within-grid concentration variability in air quality models. Atmos. Environ. 2012, 49, 348-360. [CrossRef]

39. Peters, J.M.; Avol, E.; Gauderman, W.J.; Linn, W.S.; Navidi, W.; London, S.J.; Margolis, H.; Rappaport, E.; Vora, H.; Gong, H.; et al. A study of twelve Southern California communities with differing levels and types of air pollution: II. Effects on pulmonary function. Am. J. Respir. Crit. Care Med. 1999, 159, 768-775. [CrossRef] [PubMed]

40. Lee, S.J.; Demokritou, P.; Koutrakis, P.; Delgado-Saborit, J.M. Development and evaluation of personal respirable particulate sampler (PRPS). Atmos. Environ. 2006, 40, 212-224. [CrossRef]

41. Martonchik, J.V.; Kahn, R.; Diner, D.J. Retrieval of aerosol properties over land using MISR observations. In Satellite Aerosol Remote Sensing Over land; Kokhanovsky, A.A., de Leeuw, G., Eds.; Springer: Berlin/Heidelberg, Germany, 2009; pp. 267-293.

42. Dey, S.; Di Girolamo, L. A climatology of aerosol optical and microphysical properties over the Indian subcontinent from 9 years (2000-2008) of Multiangle Imaging Spectroradiometer (MISR) data. J. Geophys. Res. 2010, 115, D15204. [CrossRef]

43. Cressie, N.A. Statistics for Spatial Data; Revised Edition; John Wiley \& Sons: New York, NY, USA, 2015; 928p.

44. Sardar, S.B.; Fine, P.M.; Sioutas, C. Seasonal and spatial variability of the size-resolved chemical composition of particulate matter $\left(\mathrm{PM}_{10}\right)$ in the Los Angeles Basin. J. Geophys. Res. 2005, 110, D07S08. [CrossRef]

45. Bell, M.L.; Ebisu, K.; Peng, R.D. Community-level spatial heterogeneity of chemical constituent levels of fine particulates and implications for epidemiological research. J. Expo. Sci. Environ. Epidemiol. 2010, 21, 372-384. [CrossRef] [PubMed]

46. Gauderman, W.J.; Avol, E.; Lurmann, F.; Kuenzli, N.; Gilliland, F.; Peters, J.; McConnell, R. Childhood asthma and exposure to traffic and nitrogen dioxide. Epidemiology 2005, 16, 737-743. [CrossRef] [PubMed]

47. Eckel, S.P.; Berhane, K.; Salam, M.T.; Rappaport, E.B.; Linn, W.S.; Bastain, T.M.; Zhang, Y.; Lurmann, F.; Avol, E.L.; Gilliland, F.D. Residential traffic-related pollution exposures and exhaled nitric oxide in the children's health study. Environ. Health Perspect. 2011, 119, 1472-1477. [CrossRef] [PubMed]

48. Health Effects Institute. Traffic Related Air Pollution: A Critical Review of the Literature on Emissions, Exposure, and Health Effects; Special Report 17; Health Effects Institute: Boston, MA, USA, 2010. 
49. Paciorek, C.J.; Liu, Y. Limitations of remotely sensed aerosol as a spatial Proxy. Environ. Health Perspect. 2009, 117, 904-909. [CrossRef] [PubMed]

50. Jerrett, M.; Turner, M.C.; Beckerman, B.S.; Arden Pope, C., III; van Donkelaar, A. Comparing the health effects of ambient particulate matter estimated using ground-based versus remote sensing exposure estimates. Environ. Health Perspect. 2017, 552, 552-560. [CrossRef] [PubMed] 